\title{
Analysis of Corporate Governance and Technological Innovation based on a Certain Industry
}

\author{
Yukun Liu \\ Asia Australia Business College, Liaoning University, Shenyang, China \\ unbelievableliuyk@163.com
}

\begin{abstract}
According to the importance degree of technological innovation in different industries, factors and intensity influencing innovation are different. Enterprises should have a matching corporate governance structure to carry out effective innovation activities. Using data of Chinese listed companies from 2015 to 2018, this paper analyzes and compares the impact of corporate governance on technological innovation in labor-intensive, capital-intensive and technologyintensive industries. Results show both similarities and differences exist in the relationship between corporate governance and technological innovation in the three industries. Previous literatures mainly focused on the relationship between corporate governance and innovation in a single industry, ignoring the comparison among different industries. By analyzing differences among industries, this paper proposes corporate governance should be matched with the characteristics of industries to better improve innovation, which is the application and expansion of the corporate governance theory in the field of innovation.
\end{abstract}

Keywords: Corporate Governance; Technological Innovation; Comparison by Industry.

\section{Introduction}

In the era of knowledge-based economy in the 21 st century, with the acceleration of the process of global economic integration and the increasingly fierce competition in the international market, technological innovation has become a focus of economic and social issues. Nowadays, China has entered the critical period of growth power conversion, facing the pressure of supply-side reform and production efficiency improvement internally, and confronting the uncertainty of trade conditions as well as financial environment transformations externally. The Nineteenth National Congress of the Party regarded innovation as "the first motive force leading development ". As one of concrete contents in the first motive, technological innovation is the core impetus to promote the rapid economic growth and the power of speeding up the development of enterprises. This paper analyzes relationship between corporate governance elements and technological innovation.

\section{Literature Review}

For relationship between corporate governance and innovation, scholars mainly focus on the influence of corporate governance factors such as equity structure, board structure and incentive mechanism on technological innovation of enterprises.

First, equity structure: Baysinger(1991) acknowledged equity concentration has a positive impact on technological innovation investment. Conversely, Bai et al. (2008) obtained a U relationship between the equity concentration and innovation. Second, the structure of the board of directors: Shaker (2000) thought the proportion of external directors can be negatively related to technological innovation. Conversely, Feng et al. (2007) believed the independent director system can improve development of enterprise innovation. 


\section{Data Description and Theoretical Analysis}

\subsection{Data Description}

Using the CSMAR database, this paper analyzes listed companies in various industries from 2015 to 2018. The total number of observations is 10711. After excluding extreme value, abnormal value and incomplete data, the number of various variables is 9912 , accounting for $92 \%$ of the number before processing. The data is representative and can be used for subsequent analysis.

\subsection{Theoretical Analysis}

Since the remuneration of managers is usually a short-term incentive, managers are more inclined to short-term cash out but ignore the long-term development. Long-term incentive policies can unify individual targets of managers and long-term goals of the enterprise.

Hypothesis 1: Salary and equity incentives promote innovation.

Independent directors are different from internal directors because they have richer industry background and knowledge. Therefore, they can better find opportunities for innovation. Separation of the two positions enables the company to use directors to monitor the general manager to ensure the effectiveness of innovation decisions.

Hypothesis 2: The independence of the board of directors and the separation of the two positions of chairman and general manager has a positive impact on innovation investment.

According to above theoretical analysis and assumptions, the following regression model is constructed to study how corporate governance affects the enterprise technological innovation:

$$
\text { Innov }_{i, t}=\partial+\beta_{1} \text { incentive }_{i, t}+\beta_{2} \text { board }_{i, t}+\beta_{3} \text { shareholder }_{i, t}+\sum_{i \geqslant 4} \beta_{i} \text { control }_{i, t}+\varepsilon_{i, t}
$$

In the formula, $i$ and $t$ represent industry and time. $\partial$ is the constant term and $\varepsilon_{i, t}$ is the error term. Meanings of variables are as follows:

This paper uses the proportion of $\mathrm{R} \& \mathrm{D}$ expenditure to operating income $(r d$ in) to measure the intensity of technological innovation. Explained variables mainly include :(1) incentive mechanism: a. salary incentive, expressed by the total annual salary of directors, supervisors and senior executives (salary, billion yuan). b. equity incentive, expressed by directors, supervisors and senior executives' shareholding ratio sum (equity). Incentive (tech) of technicians is expressed as 1 if equity incentive is in place and expressed as 0 if there is no equity incentive. (2) board structure: a. board size, expressed by the total number of directors(board). b. independence of directors, expressed as the proportion of independent directors (indepen) in the board. c. leadership structure of the board of directors, expressed by the separation of chairman and general manager. 1 and 2 represent the combination and division of the two positions respectively. (3) Equity balance: a. equity concentration: using the largest shareholder's shareholding ratio (share 1$)$ and its square (s_share 1$)$. b. equity balance: measured by the sum of the second to tenth largest shareholder shareholding ratios (share2). Separation of ownership and control: measured by difference (separation) between control and ownership. Control variables include :1) enterprise size. selecting operating income to represent enterprise scale (size). (2) asset-liability ratio. (3) industry effects (indus). (4) annual effects (year), this paper set up four annual virtual variables with 2015 as reference to control the impact of time on the innovation.

\section{Empirical Results and Analysis}

\subsection{Descriptive Statistics}

Descriptive statistical is shown in Table 1. Lower and upper quartile of the ratio $\mathrm{R} \& \mathrm{D}$ expenditure to operating income are 0.0191 and 0.054 , indicating innovation investment of listed companies is 
Volume 15 (2021)

different. For board structure, lower and upper quartile of the proportion of independent directors are 0.3333 and 0.4286 , indicating independence of directors is basically uniform. Results of the second to tenth largest shareholders' shareholding ratio are all smaller than results of the first largest shareholder's shareholding, implying the phenomenon of a single-large shareholder is common.

Table 1. Descriptive statistics

\begin{tabular}{|c|c|c|c|c|c|c|c|c|c|}
\hline variables & explanations & observation & average & standard deriatioin & $\min$ & $\max$ & p25 & median & $\mathrm{p} 75$ \\
\hline rd_in & innoration expenditure/operating income & 9912 & 0.046 & 0.0481 & 0.00002 & 0.583 & 0.0191 & 0.0359 & 0.054 \\
\hline equity & $\begin{array}{l}\text { directors, superrisors and senior executives' } \\
\text { shareholding ratio sum }\end{array}$ & 9912 & 0.202 & 0.271 & 0 & 1 & 0.0001 & 0.355 & 0.3714 \\
\hline salary & $\begin{array}{l}\text { directors, supervisors and senior executives' } \\
\text { remuneration sum }\end{array}$ & 9912 & 0.0646 & 0.0494 & 0 & 0.376 & 0.03344 & 0.05068 & 0.0784 \\
\hline tech & equity incentive to technicians & 9912 & 0.169 & 0.375 & 0 & 1 & $\mathbf{0}$ & 0 & 0 \\
\hline board & quality of directors & 9912 & 8.426 & 1.675 & 4 & 17 & 7 & 9 & 9 \\
\hline indepen & proportion of independent directors & 9912 & 0.377 & 0.0569 & 0 & 0.75 & 0.3333 & 0.3636 & 0.4286 \\
\hline dir_ceo & $\begin{array}{l}\text { seperation of the chairman and general } \\
\text { manager }\end{array}$ & 9912 & 1.716 & 0.451 & 1 & 2 & 1 & 2 & 2 \\
\hline seperation & seperation of control and ownership & 9912 & 0.0394 & 0.0723 & 0 & 0.595 & $\mathbf{0}$ & 0 & 0.0493 \\
\hline share1 & share proportion of the largest shareholder & 9912 & 0.334 & 0.142 & 0 & 0.882 & 0.2253 & 0.3124 & 0.4251 \\
\hline s_share1 & $\begin{array}{l}\text { square of the share proportion of the largest } \\
\text { shareholder }\end{array}$ & 9912 & 0.132 & 0.11 & 0 & 0.779 & 0.0508 & 0.0976 & 0.1807 \\
\hline share2 & $\begin{array}{l}\text { share proportion of the second to tenth } \\
\text { largest shareholder }\end{array}$ & 9912 & 0.262 & 0.132 & 0 & 0.809 & 0.1593 & 0.2556 & 0.353 \\
\hline ratio & debt to asset ratio & 9912 & 0.408 & 0.2031 & 0.0174 & 1.951 & 0.2461 & 0.3877 & 0.5483 \\
\hline size & operating income & 9912 & 3.004 & 1.392 & -1.748 & 9.861 & 2.0161 & 2.8502 & 3.8143 \\
\hline
\end{tabular}

Table 2. Classification of industry

\begin{tabular}{|c|c|c|}
\hline . labor-intensive & capital-intensive & technology-intensive \\
\hline A argriculture,foresty, animal husbandry and fishery & C3 papernaking, printing & C5 electronic engineering \\
\hline F transport, warehousing & C4 petrolenm,chemical,plastic cment,plastic & C7 machine, equipment, instrument \\
\hline H wholesale and retail & C6 metal, nonnetal & C8 medicine, biological products \\
\hline L connunication and culture & J real estate & C9 other manufacturing \\
\hline C2 lnubering, furniture & K social service & G infornation technology \\
\hline D production and supply of electricity, gas and water & & \\
\hline
\end{tabular}

Table 3. Regression by industry

\begin{tabular}{|c|c|c|c|}
\hline variables & labor-intensive & capital-itensive & technology-intensive \\
\hline \multirow[t]{2}{*}{ equity } & $0.022^{+ \pm \star}$ & $0.014^{\star \star \star}$ & $0.005^{\star \star}$ \\
\hline & (5.79) & $(5.00)$ & $(2.02)$ \\
\hline \multirow[t]{2}{*}{ salary } & $0.072^{\star \star \star}$ & $0.044^{\star \star \star}$ & $0.217^{* * *}$ \\
\hline & (4.16) & (3.14) & (16.13) \\
\hline \multirow[t]{2}{*}{ tech } & 0.00016 & $0.004^{\star \star}$ & $0.014^{* \star *}$ \\
\hline & $(0.07)$ & (2.32) & (9.68) \\
\hline \multirow[t]{2}{*}{ board } & $0.00 z^{\star \star \star}$ & $0.001^{*}$ & 0.0001 \\
\hline & (4.28) & (1.90) & (0.25) \\
\hline \multirow[t]{2}{*}{ indepen } & $0.053^{+ \pm+}$ & $0.032^{+\infty}$ & $0.044^{*+*}$ \\
\hline & (3.91) & (2.12) & (3.79) \\
\hline \multirow[t]{2}{*}{ dir_ceo } & $0.004^{\star *}$ & $0.003^{* *}(2.05)$ & $-0.005^{\star \star *}$ \\
\hline & (2.12) & (2.05) & $(-3.84)$ \\
\hline \multirow[t]{2}{*}{ seperation } & $0.003(0.36)$ & $0.011(1.12)$ & -0.001 \\
\hline & $(0.36)$ & (1.12) & $(-0.10)$ \\
\hline \multirow[t]{2}{*}{ share1 } & $-0.069 * * *$ & $-0.066^{* \star *}$ & $-0.084^{\star \star \star}$ \\
\hline & $(-3.28)$ & $(-3.27)$ & $(-4.99)$ \\
\hline \multirow[t]{2}{*}{ s_share1 } & $0.077^{\star \star \star \star}$ & 0.003 & $0.043^{* *}$ \\
\hline & (2.78) & (0.54) & $(2.00)$ \\
\hline \multirow[t]{2}{*}{ share2 } & -0.008 & $0.099^{\star \star \star \star}$ & $-0.040^{\star \star *}$ \\
\hline & $(-1.20)$ & (3.85) & $(-7.92)$ \\
\hline \multirow[t]{2}{*}{ ratio } & $-0.008^{* \star}$ & $-0.014^{* \star \star}$ & $-0.026^{* \star \star}$ \\
\hline & $(-2.03)$ & $(-3.69)$ & $(-7.91)$ \\
\hline \multirow[t]{2}{*}{ size } & $-0.007^{\star * *}$ & $-0.009^{* * *}$ & $-0.012^{* * *}$ \\
\hline & $(-10.26)$ & $(-13.62)$ & $(-21.89)$ \\
\hline observations & 1478 & 1690 & 6744 \\
\hline$R$-squared & 0.167 & 0.22 & 0.19 \\
\hline
\end{tabular}

Note: t-statistics in parentheses $* * * \mathrm{p}<0.01, * * \mathrm{p}<0.05, * \mathrm{p}<0.1$ 
Volume 15 (2021)

\subsection{Regression Results by Industry}

This paper classifies 21 industries to labor-intensive, capital-intensive and technology-intensive three categories based on industry classification results of Dang and Lu (2014). Industry division criteria is shown in Table 2 and regression results are shown in Table 3.

Regression results show similarities in the industries: results in incentive mechanism are basically the same. Proportion of independent directors is positively related to innovation investment. For equity structure, since the coefficients of the shareholding ratio of the first largest shareholder are negative, and coefficients of its square are positive, a significant $U$ relationship between equity concentration and innovation proved.

Labor-intensive industries and capital-intensive industries have commonalities. First, separation of chairman and general manager has a significant positive impact on technological innovation. Independent supervision to managers by the board of directors is conducive to innovation in laborintensive and capital-intensive industries. Second, separation degree of control and ownership of the main controller is positively related to innovation.

The tool variable method is used to handle endogenous problems. Salary incentive plans for management in a company needs to take incentive provided by other competitors in the industry into consideration, and incentive compensation provided by competitors should not have a direct impact on the innovation of the enterprise. Therefore, this paper uses directors, supervisors and senior managers' salary-industry average as a tool variable. Table 4 shows regression results using the tool variable. After excluding the endogeneity, regression results are basically consistent with the above, so the hypotheses are basically verified.

Table 4. Tool variables analysis

\begin{tabular}{|c|c|c|c|}
\hline variables & labor-intensive & capital-itensive & technology-intensive \\
\hline \multirow[t]{2}{*}{ equity } & $0.023 * * *$ & $0.014 * * *$ & $0.829 * *$ \\
\hline & (5.95) & (4.83) & (2.30) \\
\hline \multirow[t]{2}{*}{ salary } & 0.012 & -0.054 & $0.008^{* *}$ \\
\hline & $(0.21)$ & $(-0.66)$ & $(2.37)$ \\
\hline \multirow[t]{2}{*}{ tech } & 0.0001 & $0.005^{* * *}$ & $0.008^{* *}$ \\
\hline & $(0.10)$ & $(2.60)$ & $(2.02)$ \\
\hline \multirow[t]{2}{*}{ board } & $0.002 * * *$ & $0.001^{* *}$ & -0.002 \\
\hline & (4.37) & (2.13) & $(-1.47)$ \\
\hline \multirow[t]{2}{*}{ indepen } & $0.054^{* * *}$ & $0.032 * *$ & $0.028 *$ \\
\hline & (3.99) & (2.13) & $(1.69)$ \\
\hline \multirow[t]{2}{*}{ dir_ceo } & $0.003^{* *}$ & $0.004^{* *}$ & $-0.005^{* * *}$ \\
\hline & (1.98) & $(2.22)$ & $(-3.21)$ \\
\hline \multirow[t]{2}{*}{ seperation } & 0.005 & 0.011 & -0.016 \\
\hline & $(0.59)$ & (1.17) & $(-1.26)$ \\
\hline \multirow[t]{2}{*}{ share1 } & $-0.073 * * *$ & $-0.071^{* * *}$ & -0.025 \\
\hline & $(-3.42)$ & $(-3.40)$ & $(-0.64)$ \\
\hline \multirow[t]{2}{*}{ s_share1 } & $0.078^{* \star *}$ & $0.103^{* \star *}$ & -0.011 \\
\hline & (2.84) & (3.95) & $(-0.28)$ \\
\hline \multirow[t]{2}{*}{ share2 } & -0.007 & 0.009 & $-0.054 * \star *$ \\
\hline & $(-1.13)$ & 0.01 & $(-5.30)$ \\
\hline \multirow[t]{2}{*}{ ratio } & -0.009 ** & $-0.016^{* * *}$ & $-0.016^{* *}$ \\
\hline & $(-2.24)$ & $(-3.79)$ & $(-2.16)$ \\
\hline \multirow[t]{2}{*}{ size } & $-0.006 * * *$ & $-0.008^{* * *}$ & $-0.023 * * *$ \\
\hline & $(-4.65)$ & $(-5.06)$ & $(-3.66)$ \\
\hline observations & 1,478 & 1,690 & 6,744 \\
\hline
\end{tabular}


Volume 15 (2021)

\subsection{Robustness Test}

To ensure the accuracy and reliability of the conclusion, this paper carries out two robustness tests. One is to replace the dependent variable with the proportion of R \& D technicians ( R \& D technicians / total staff, employ), and the other is to add the regional marketization factor(market) to independent variables.

Table 5. Robustness test 1

\begin{tabular}{|c|c|c|c|}
\hline variables & labor-intensive & capital-itensive & technology-intensive \\
\hline \multirow[t]{2}{*}{ equity } & $0.094^{2+4}$ & $0.067^{* * *}$ & $0.026^{*+*}$ \\
\hline & (6.56) & (7.61) & (3.43) \\
\hline \multirow[t]{2}{*}{ salary } & 0.074 & -0.031 & $0.386^{*+4}$ \\
\hline & (1.17) & $(-0.71)$ & (9.61) \\
\hline \multirow[t]{2}{*}{ tech } & $0.021^{4+4}$ & $0.015^{4+4}$ & $0.045^{+\star 4}$ \\
\hline & (2.53) & $(2.70)$ & (10.22) \\
\hline \multirow[t]{2}{*}{ board } & 0.002 & $-0.004^{+\star}$ & $0.002^{*}$ \\
\hline & (1.24) & $(-2.42)$ & (1.89) \\
\hline \multirow[t]{2}{*}{ indepen } & 0.017 & $-0.104^{+\star}$ & $0.135^{++t}$ \\
\hline & $(0.35)$ & $(-2.27)$ & (3.87) \\
\hline \multirow[t]{2}{*}{ dir_ceo } & 0.010 & $0.015^{++t+}$ & $-0.012^{+\star \star+}$ \\
\hline & (1.51) & $(3.07)$ & $(-2.99)$ \\
\hline \multirow[t]{2}{*}{ seperation } & 0.018 & 0.036 & $-0.078^{\star \star \star}$ \\
\hline & $(0.53)$ & (1.23) & $(-3.01)$ \\
\hline \multirow[t]{2}{*}{ share1 } & -0.051 & 0.011 & $-0.225^{\star \star \star}$ \\
\hline & $(-0.66)$ & $(0.18)$ & $(-4.49)$ \\
\hline \multirow[t]{2}{*}{ s_sharel } & 0.058 & 0.030 & 0.090 \\
\hline & $(0.57)$ & $(0.38)$ & $(1.40)$ \\
\hline \multirow[t]{2}{*}{ share2 } & -0.008 & -0.007 & $-0.080^{\star \star \star *}$ \\
\hline & $(-0.35)$ & $(-0.39)$ & $(-5.33)$ \\
\hline \multirow[t]{2}{*}{ ratio } & -0.008 & -0.017 & $-0.072^{\star \star \star}$ \\
\hline & $(-0.60)$ & $(-1.51)$ & $(-7.24)$ \\
\hline \multirow[t]{2}{*}{ size } & $-0.011^{\star \star \star}$ & $-0.013^{\star \star \star}$ & $-0.022 \star \star \star \star$ \\
\hline & $(-4.10)$ & $(-6.17)$ & $(-13.41)$ \\
\hline observations & 1478 & 1690 & 6744 \\
\hline$R$-squared & 0.073 & 0.14 & 0.14 \\
\hline
\end{tabular}

Regression results of the first robustness test show in Table 5. The influence of the remuneration incentive is still significant in technology-intensive enterprises. In the second robustness test, the regional marketization is added to explanatory variables, and regression results are shown in Table 6 . Referring to the market index in 2016, the average value of the market index is 6.72 , and provinces above the average value present as 1 and below as 0 . Based on the province where the enterprise is 
registered, the marketization degree of each enterprise is obtained. After considering the degree of marketization, regression results are basically consistent with previous ones, so the reliability of results are proved.

Table 6. Robustness test 2

\begin{tabular}{|c|c|c|c|c|c|c|}
\hline \multirow[t]{2}{*}{ variables } & \multicolumn{2}{|c|}{ labor-intensive } & \multicolumn{2}{|c|}{ capital-intensive } & \multicolumn{2}{|c|}{ technology-intensivve } \\
\hline & $r d_{-}^{i n}$ & employ & $r d$ in & employ & $r d_{-}$in & employ \\
\hline \multirow[t]{2}{*}{ market } & $0.009+* *$ & $0.023^{*+*}$ & $0.005^{*+* t}$ & $0.025^{*+*}$ & $0.009+* t$ & $0.039+t+$ \\
\hline & $(4.90)$ & (3.31) & (2.67) & (4.14) & $(4.44)$ & $(6.86)$ \\
\hline \multirow[t]{2}{*}{ equity } & $0.022^{* * *}$ & $0.092^{2 * *}$ & $0.013 * * *$ & $0.062^{* * *}$ & 0.004 & $0.020^{* * * *}$ \\
\hline & (5.72) & $(6.50)$ & $(4.63)$ & $(7.07)$ & (1.50) & (2.62) \\
\hline \multirow[t]{2}{*}{ salary } & $0.063^{* * *}$ & 0.052 & $0.040 * \ldots *$ & -0.048 & $0.215^{* * *}$ & $0.375^{* . *}$ \\
\hline & $(3.66)$ & $(0.83)$ & $(2.87)$ & $(-1.12)$ & (15.96) & (9.36) \\
\hline \multirow[t]{2}{*}{ tech } & 0.0001 & $0.021^{+*}$ & $0.004^{+*}$ & $0.013^{+*}$ & $0.014^{t+4 t}$ & $0.044^{+* t+}$ \\
\hline & $(0.06)$ & (2.53) & $(2.06)$ & (2.31) & $(9.50)$ & $(9.97)$ \\
\hline \multirow[t]{2}{*}{ board } & $0.002^{*+*}$ & 0.002 & $0.001^{+*}$ & $0.003^{*+}$ & $0.0001(0.6)$ & 0.002 \\
\hline & (4.42) & (1.32) & (2.14) & $(2.05)$ & $(0.6)$ & (1.34) \\
\hline \multirow[t]{2}{*}{ indepen } & 0.001 & 0.019 & $0.035^{* *}$ & 0.16617 & $0.048^{+2.4}$ & $0.153^{+.4}$ \\
\hline & (0.16) & $(0.38)$ & (2.35) & 0.001 & (4.12) & $(4.40)$ \\
\hline \multirow[t]{2}{*}{ dir_ceo } & $0.054^{t+* t}$ & $0.010^{*}$ & $0.003^{* *}$ & $0.015^{t+*}$ & $-0.005^{*+*}$ & $-0.012^{*+*}$ \\
\hline & (3.99) & (1.67) & (2.11) & (3.17) & $(-3.87)$ & $(-3.04)$ \\
\hline \multirow[t]{2}{*}{ seperation } & $0.004^{* t}$ & -0.023 & 0.011 & 0.035 & -0.002 & $-0.084^{+* * *}$ \\
\hline & (2.36) & $(-0.66)$ & (1.13) & (a.21) & $(-0.24)$ & $(-3.24)$ \\
\hline \multirow[t]{2}{*}{ share1 } & $-0.070^{4 . * *}$ & -0.054 & $-0.065^{* * *}$ & 0.020 & $-0.0833^{* * t}$ & $-0.223^{*+*}$ \\
\hline & $(-3.34)$ & $(-0.69)$ & $(-3.19)$ & (0.32) & $(-4.98)$ & $(-4.47)$ \\
\hline \multirow[t]{2}{*}{ s_sharel } & $0.078^{* * *}$ & 0.061 & $0.096 * * *$ & 0.016 & $0.043^{* *}$ & 0.092 \\
\hline & (2.84) & $(0.60)$ & (3.74) & $(0.21)$ & (2.02) & (1.44) \\
\hline \multirow[t]{2}{*}{ share2 } & -0.010 & -0.015 & 0.002 & -0.012 & $-0.041 \ldots$ & $-0.083 * * *$ \\
\hline & $(-1.62)$ & $(-0.64)$ & (0.35) & $(-0.67)$ & $(-8.06)$ & $(-5.55)$ \\
\hline \multirow[t]{2}{*}{ ratio } & -0.006 & -0.004 & $-0.013^{* * *}$ & -0.012 & $-0.026^{+t+t}$ & $-0.071^{+* *}$ \\
\hline & $(-1.59)$ & $(-0.29)$ & $(-3.38)$ & $(-1.06)$ & $(-7.82)$ & $(-7.12)$ \\
\hline \multirow[t]{2}{*}{ size } & $-0.008^{* * *}$ & $-0.012 * * *$ & $-0.009 * \cdots$ & $-0.013^{* * *}$ & $-0.012 * * *$ & $-0.023 * * *$ \\
\hline & $(-10.73)$ & $(-4.39)$ & $-13.71)$ & $(-6.31)$ & $(-22.08)$ & $(-13.71)$ \\
\hline observations & 1478 & 1478 & 1690 & 1690 & 6744 & 674 \\
\hline$R$-squared & 0.18 & 0.079 & 0.223 & 0.149 & 0.192 & 0.146 \\
\hline
\end{tabular}

Note: $t$-statistics in parentheses $* * * p<0.01,{ }^{* *} p<0.05,{ }^{*} p<0.1$

\section{Main Conclusions and Policy Recommendations}

This paper examines common and different effects of corporate governance on technological innovation in three industries and draws following conclusions: the commonality in three industries (1) salary and equity incentive have a significant positive impact on the technological innovation;(2) The size of the board of directors and independence of directors are conducive to innovation;(3) $U$ relationship between equity concentration and innovation investment exist. Differences among industries, reflecting in technology-intensive industry :(1) The impact of equity incentives of technicians on innovation investment is significant;(2) Separation of chairman and general manager is not conducive to innovation;(3) Equity balance is negatively related with innovation. Based on conclusions, this paper puts forward the following policies: enterprises should (1) establish a good incentive mechanism, improving the executive compensation, and adopt the long-term incentive mechanism such as the equity incentive. In addition, technology-intensive enterprises should also 
focus on rewards of technicians; (2) prevent ownership structure from being too dispersive;(3) improve the board system and improve independence of directors.

\section{References}

[1] Baysinger BD, Kosnik RD\& Turk TA.1991. Effects of board and ownership structure on corporate R\&D strategy. Academy of Management Journal 34(1):205-214.

[2] Feng GF\& Wen J. 2008. An Empirical Analysis of the Relationship between Corporate Governance and Technological Innovation of Listed Companies in China. China Industrial Economy 7: 91-101.

[3] Lu T \& Dang Y. 2014. Corporate governance and technological innovation: a comparison by industry. Economic Studies 49(06):115-128. 